\title{
Molecular Modeling and Inhibitory Activity of Cowpea Cystatin against Bean Bruchid Pests
}

\author{
Juliana M. Aguiar, ${ }^{1}$ Octávio L. Franco, ${ }^{2,3}$ Daniel J.Rigden, ${ }^{2,4}$ Carlos Bloch, Jr., ${ }^{2}$ Ana C.S. Monteiro, ${ }^{5}$ \\ Victor M.Q. Flores, ${ }^{6}$ Tânia Jacinto, ${ }^{6}$ José Xavier-Filho, ${ }^{1}$ Antonia E.A. Oliveira, ${ }^{1}$ Maria F. Grossi-de-Sá, ${ }^{2}$ and \\ Kátia V.S. Fernandes ${ }^{1 *}$ \\ ${ }^{1}$ Laboratório de Química e Função de Proteínas e Peptídeos, UENF, Campos dos Goytacazes, R.J., Brazil \\ ${ }^{2}$ National Centre of Genetic Resources and Biotechnology, Cenargen/Embrapa, Brasilia, Brazil \\ ${ }^{3}$ Centro de Análises Proteômicas e Bioquímicas, Pós-Graduação em Ciências Genômicas e Biotecnologia, UCB, \\ Brasília-DF, Brazil \\ ${ }^{4}$ School of Biological Sciences, University of Liverpool, Liverpool, United Kingdom \\ ${ }^{5}$ Instituto de Biofísica Carlos Chagas Filho (IBCCF), Rio de Janeiro, Brazil \\ ${ }^{6}$ Laboratório de Biotecnologia, UENF, R.J., Brazil
}

\begin{abstract}
Plant cystatins show great potential as tools to genetically engineer resistance of crop plants against pests. Two important potential targets are the bean weevils Acanthoscelides obtectus and Zabrotes subfasciatus, which display major activities of digestive cysteine proteinases in midguts. In this study a cowpea cystatin, a cysteine proteinase inhibitor found in cowpea (Vigna unguiculata) seeds, was expressed in Escherichia coli and purified with a Ni-NTA agarose column. It strongly inhibited papain and proteinases from midguts of both A. obtectus and Z. subfasciatus bruchids, as seen by in vitro assays. When the protein was incorporated into artificial seeds at concentrations as low as $0.025 \%$, and seeds were consumed by the bruchids larva, dramatic reductions in larval weight, and increases in insect mortality were observed. Molecular modeling studies of cowpea cystatin in complex with papain revealed that five $\mathrm{N}$-terminal residues responsible for a large proportion of the hydrophobic interactions involved in the stabilization of the enzyme-inhibitor complex are absent in the partial $\mathrm{N}$-terminal amino acid sequencing of soybean cystatin. We suggest that this structural difference could be the reason for the much higher effectiveness of cowpea cystatin when compared to that previously tested phytocystatin. The application of this knowledge in plant protein mutation programs aiming at enhancement of plant defenses to pests is discussed. Proteins 2006;63:662-670. $\odot 2006$ Wiley-Liss, Inc.
\end{abstract}

Key words: Acanthoscelides obtectus; bean weevil; cysteine proteinase inhibitor; molecular modeling; plant defense; Zabrotes subfasciatus

\section{INTRODUCTION}

Most plant species produce proteinase inhibitors (PIs) in their seeds, tubers, and leaves as a general constitutive defense against a diverse set of predators. ${ }^{1}$ The majority of those is active against the serine and cysteine class of proteinases and is able to form stable complexes with target proteinases, blocking, altering, or preventing access to the enzyme active site. ${ }^{2}$ During plant predation by insect pests, PIs act directly on gut proteases by attenuating amino acid assimilation and slowing their growth. ${ }^{3}$

Besides the most-studied serine PIs, phytocystatins have also been involved in several responsive processes induced by fungal and abiotic stress ${ }^{4,5}$ as well as by phytophagous predators. ${ }^{2,6-15}$ On this basis, several transgenic plants have been produced expressing specific phytocystatins and tested for enhanced resistance against predators. ${ }^{2,9,16-25}$ This class of inhibitor is among the most promising candidates for bettering plant defenses against insects ${ }^{23-26}$ nematodes, ${ }^{2,19,21,27-29}$ slugs,${ }^{13}$ and fungi infection. ${ }^{30-33}$

The known abundance of cysteine proteinases in bruchid midguts $^{34}$ renders these digestive enzymes promising targets for phytocystatins. Among the most important legume crop weevils are the bean weevil Acanthoscelides obtectus and the Mexican bean weevil Zabrotes subfasciatus, which currently cause serious damage to stored seeds of Phaseolus vulgaris. It is largely accepted that the coevolution of plants and their predators has led to an adaptation of phytophagous insects to the deterrent compounds present in the plants they feed on. ${ }^{35}$ Related literature describes, for example, the lack of effects of plant proteinase- and $\alpha$-amylase inhibitors upon the digestive enzymes of insects adapted to a particular plant species. ${ }^{3,36,37}$ The same inhibitors are, on the other hand, very efficient in blocking enzymes from organisms that do not feed on that plant. Thus, the genetic engineering of plants aiming to increase resistance to insect predation may rely exclusively on the repertoire of genes found in plants. $^{37}$

*Correspondence to: Kátia Fernandes, Av. Alberto Lamego, 2000, Horto; Campos dos Goytacazes, RJ, Brazil. E-mail: cowpkat@uenf.br

Received 3 October 2005; Revised 14 November 2005; Accepted 15 November 2005

Published online 8 February 2006 in Wiley InterScience (www.interscience.wiley.com). DOI: 10.1002/prot.20901 
Following this strategy, in this work we explore the in vitro and in vivo insecticidal properties of a cowpea cystatin (CCPI) against $P$. vulgaris major bruchid pests and demonstrate much larger effects than those seen for other cystatins. A molecular model of CCPI in complex with papain is used to analyze characteristics of the phytocystatin-cysteine proteinase interaction and to explain the unusual potency of the cowpea inhibitor.

\section{MATERIALS AND METHODS Expression of Cowpea Cystatin (CCPI) in Bacteria}

The cowpea cystatin (CCPI) cDNA, cloned from Vigna unguiculata, ${ }^{38}$ was inserted into the pQE30 expression vector $^{2}$ and the construct was used for transformation of Escherichia coli M15 strain (pREP4). LB medium (1L) containing $100 \mathrm{mg} \cdot \mathrm{mL}^{-1}$ ampicillin was employed for bacteria growth at $37^{\circ} \mathrm{C}$ with constant shaking. After the optical density at $600 \mathrm{~nm}$ of the culture reached 0.6, 0.05 mM IPTG was added to induce expression and growth was continued for other $3 \mathrm{~h}$. Similar levels of expression for IPTG concentrations in the range of 0.05 to $0.4 \mathrm{mM}$ were previously observed. After induction, the culture was centrifuged at $10.000 \times g$ for $10 \mathrm{~min}$, supernatant was discarded, and the pellet was resuspended in $25 \mathrm{~mL}$ of lyses buffer ( $50 \mathrm{mM}$ sodium phosphate, $300 \mathrm{mM}$ sodium chloride, $10 \mathrm{mM}$ imidazole). Bacterial cells were sonicated for $30 \mathrm{~min}$. The bacterial extract was centrifuged at $10,000 \times g$ for $10 \mathrm{~min}$ and the supernatant was reserved.

\section{Purification of the Recombinant Cystatin Using Ni-NTA Agarose}

The bacterial extract containing CCPI was mixed to the Ni-NTA Agarose (Qiagen) matrix, previously equilibrated with above lyses buffer, $\mathrm{pH} 8.0$, followed by an incubation of $45 \mathrm{~min}$ at $4^{\circ} \mathrm{C}$, using batch chromatography. Nonretained material was removed by washing the matrix with four volumes of wash buffer, $\mathrm{pH} 8.0(50 \mathrm{mM}$ sodium phosphate, $300 \mathrm{mM}$ sodium chloride, and $20 \mathrm{mM}$ imidazole). Retained materials were eluted by 10 volumes of elution buffer, $\mathrm{pH} 8.0$ (50 mM sodium phosphate, $300 \mathrm{mM}$ sodium chloride, and $250 \mathrm{mM}$ imidazole).

\section{Polyacrylamide Gel Electrophoresis and Western Blotting Analysis}

Sodium dodecyl sulphate polyacrylamide gel electrophoresis (SDS-PAGE) was conducted according Laemmli ${ }^{39}$ at room temperature. Protein molecular weight markers were from Pharmacia. Bromophenol blue was used as the tracking dye. Anti-CCPI primary serum used in this work was raised in rabbit against cowpea cystatins (KVS Fernandes 1992. Thesis, Long Ashton Research Station, University of Bristol, UK), in collaboration with Dr. Robert Thornburg from Iowa State University. Purified anticowpea cystatin antibodies were obtained by affinity chromatography of the crude immune serum in a column of Protein A covalently bound to Sepharose CL-4B. Immunoblots were made using anti-CCPI antibodies at a 1:2000 dilution in blocking solution. ${ }^{40}$

\section{MALDI-TOF Analysis}

Freeze-dried samples of the chromatographically eluted proteins were desalted and prepared for Matrix-Assisted Laser Desorption Time-of-Flight Analysis (MALDI-TOF) on a Voyager-DE STR Bioworkstation (PerSeptive Biosystems, Framingham, MA). The samples were dissolved in $1.0 \%$ trifluoroacetic acid and the sinapinic acid matrix (a saturated solution dissolved in acetonitrile/0.1\% TFA 1:1, v/v) from Sigma Chemicals was added. The solution was then vortex-mixed and $1 \mathrm{~mL}$ was applied onto the Voyager Bioworkstation sample plate. Samples were air-dried at room temperature. The spectrometer, equipped with a delayed-extraction system, was operated in linear mode. Sample ions were evaporated by irradiation with an $\mathrm{N}_{2}$ laser at a wavelength of $337 \mathrm{~nm}$, and accelerated at $23 \mathrm{kV}$ potential in the ion source with a delay of $150 \mathrm{~ns}$. Samples were ionized with 100 to 200 shots of a 3 -ns pulse width laser light. The signal was digitized at a rate of $500 \mathrm{MHz}$ and averaged data was presented to a standard Voyager data system for manipulation.

\section{Proteinase Preparations}

Papain was purchased from Sigma Co., St. Louis, MO. Larval insect proteinase preparations were obtained from the bean weevils' A. obtectus and $Z$. subfasciatus and from the boll weevil Anthonomus grandis. Adult boll weevil proteinases were also isolated.

Proteinases from bruchid larvae of A. obtectus and $Z$. subfasciatus were obtained after dissection and collection of the luminal fluid from 18-20 days larvae reared in common bean ( $P$. vulgaris) seeds. Boll weevil larvae and adults were obtained from Biological Control Department of CENARGEN/EMBRAPA (Brasília, Brazil). Larvae were reared on an artificial diet ${ }^{41}$ at $25^{\circ} \mathrm{C}$ and relative humidity of $55 \%$. The midguts were surgically removed from larvae and adult insects and placed into an iso-osmotic saline $(0.15 \mathrm{M} \mathrm{NaCl})$. Midgut tissue was stirred and centrifuged for $10 \mathrm{~min}$ at $10.000 \times \mathrm{g}$ at $4^{\circ} \mathrm{C}$ and the supernatant was used for enzymatic assays.

\section{Proteinase and Proteinase Inhibitor Assays}

Stock solutions of the synthetic peptide substrate (10 $\mathrm{mM}$ Z-Phe-Arg-MCA) were made in 50\% dimethyl sulfoxide (DMSO). Its hydrolysis was followed by monitoring the fluorescence increase of released MCA, using an excitation wavelength of $340 \mathrm{~nm}$ and an emission wavelength of 480 $\mathrm{nm}$ in a Hitachi F4500 fluorimeter. Assays were performed by continuously monitoring enzyme activity from papain and insect proteinases, before and after addition of the CCPI at a $10 \mu \mathrm{M}$ concentration. Steady-state velocities before and after addition of the inhibitor were obtained by linear regression analysis. All determinations were based on assays with less than $2 \%$ of substrate hydrolysis, according to Barrett and Kirschke. ${ }^{42}$ For each assay, 100 $\mathrm{ng} / \mathrm{mL}$ of papain or proteinase extracts were used. Final data are the average among three different assays.

\section{Feeding Tests}

The effects of cowpea cystatin on insect development were examined by a feeding test using artificial seeds 
made of bean flour ( $P$. vulgaris) and three different inhibitor concentrations $(0.025,0.05$, and $0.1 \%)$. The freezedried CCPI added to the bean meal was thoroughly mixed in a mortar to ensure an uniform distribution. Each artificial seed (300 $\mathrm{mg}$ ) was made by pressing the flour in a cylindrical brass mold (10-mm diameter) with the help of a hand press. The artificial seeds were placed in a dish into which $Z$. subfasciatus adults were introduced; dishes were kept in a chamber at $28^{\circ} \mathrm{C}$ and about $80 \%$ relative humidity. After $24 \mathrm{~h}$, adults were removed and only three eggs per seed were retained. In the case of A. obtectus, three eggs per seed were manually mixed to the seeds. After 20 days, the weight of surviving larvae was measured and after 45 days, adult insects were counted. Negative controls were used in which the artificial seeds lacked cystatin. Each treatment was done with three repetitions and each replicate contained six seeds or 18 larvae.

\section{Sequence Comparisons and Threading}

Sensitive sequence comparison techniques and specialized threading methods were used to determine the best templates to use for construction of the model. Careful consideration of template choice was necessary because several proteins are known to share the cystatin fold, ${ }^{43}$ including stefins ${ }^{44}$ and monelins. ${ }^{45}$ Several methods were used to obtain a consensus view. Sequence comparisons were carried out using the $\mathrm{HMM}^{46}$ and $\mathrm{FFAS}^{47}$ methods; for threading, Genthreader, ${ }^{48}$ 3D-PSSM, ${ }^{49}$ and the Bioinbgu methods ${ }^{50}$ were applied. Structural alignment of the used templates was obtained from the FSSP database. ${ }^{51}$ Sequence alignments were manipulated using Jalview (available at http://circinus.ebi.ac.ul:6543/jalview/).

\section{Construction and Refinement of a Model for the Papain-Cowpea Cystatin Complex}

Because one of the interests of this work lays in understanding the interaction of CCPI with papain, use of the stefin-papain complex structure was obligatory. In the light of the fold recognition results we constructed a model of CCPI using information from both stefin (1stf) and chicken cystatin (1cew). Where the backbones of the two inhibitor templates adopted similar conformations, information from both was simultaneously incorporated into the modeling process. Use of multiple templates, where possible, is known to improve the quality of models. Where the templates differed, chicken cystatin alone, as the more closely related molecule to CCPI, was used. At both termini length considerations forced the use of the stefin template alone in model building. The most favorable positions for insertions and deletions in CCPI, relative to the templates, were obtained through visual examination of the templates. Papain, from 1stf model, was present throughout the model refinement to provide the correct environment for modeling of the complexed inhibitor.

The limited sequence similarity between CCPI and available templates (around $29 \%$ with chicken cystatin and $22 \%$ with stefins) led to the application of a rigorous modeling strategy in which construction and evaluation of multiple models were used to validate the target templates alignment. ${ }^{52,53}$ In this way, 10 models of the papain-CCPI complex were built, for each tested target template alignment. A 2 A coordinate randomization step was applied prior to refinement of the models to sample coordinate space. The set of models was analyzed for solvent exposure and packing with PROSA $\mathrm{II}^{54}$ and for stereochemical properties with PROCHECK. ${ }^{55}$

Each model was analyzed with MULTIDOCK, ${ }^{56}$ a program designed for refinement of complex coordinates, which alternates cycles of rigid body and side chain rotamer refinement. To allow for the possibility of side chains adopting nonrotamer conformations the results of MULTIDOCK refinement were subjected to 200 cycles of energy minimization with X-PLOR 3.851. ${ }^{57}$ A constant high dielectric constant of 5 was used because protein interfaces are known to be more polar than protein interior. ${ }^{58}$ Surface complementarities between enzyme and inhibitor and buried interface area were calculated with SC. ${ }^{59}$ In addition, enzyme-inhibitor interaction energy was calculated using X-PLOR and HBPLUS, ${ }^{60}$ used for counting hydrophobic contacts and hydrogen bonds between the proteins. The model exhibiting the greatest interface complementarities was among the best scoring by PROSA II analysis and was taken as the final model.

\section{RESULTS AND DISCUSSION Induction and Expression of Cowpea Cystatin in E. coli Cells}

The heterologously expressed cowpea cystatin was purified with a Ni-NTA agarose batch affinity chromatography. Figure 1(A) shows that proteinase inhibitory activity was only associated with the eluted fraction. This could be asserted by fluorimetric assay (black line), which shows that papain activity over Z-Phe-Arg-AMC was reduced in $100 \%$ when testing this fraction. None inhibitory activity was present in either nonretained (NR) or washed fractions (Wash). Figure 1(B) shows SDS-PAGE analysis of crude extract and fractions obtained during the purification. The total homogenate showed a major band of approximately $13 \mathrm{kDa}$ (lane EL), which elutes solely, as pure protein, with the elution buffer. This protein was positively identified by an anti-CCPI serum by Western blotting (lane Elb).

MALDI spectroscopy applied to the eluted fraction revealed a monomeric molecular mass of 10,345 $\mathrm{Da}$ and a dimeric molecular mass of 21,032 Da (Fig. 2). The molecular mass calculated by mass spectrometry agrees with the theoretical molecular mass of cowpea cystatin deduced from the cloned cDNA sequence. ${ }^{38}$ The mass is also in accordance with typical phytocystatin masses, for which a range of $10-14 \mathrm{kDa}$ is observed. ${ }^{61-63}$

\section{In Vitro Inhibitory Activity of CCPI}

Cowpea cystatin was tested against proteinase-enriched midgut extracts from different Coleopteran; the cotton boll weevil (Anthonomus grandis), the Mexican bean weevil (Zabrotes subfasciatus), and the common bean weevil (Acanthoscelides obtectus).

Figure 3 shows that CCPI has high inhibitory activity against papain and against the midgut homogenates from 


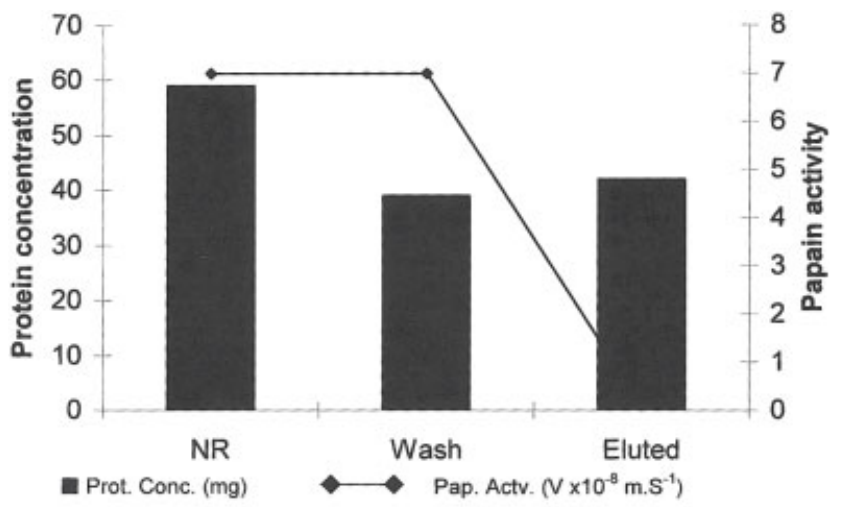

A

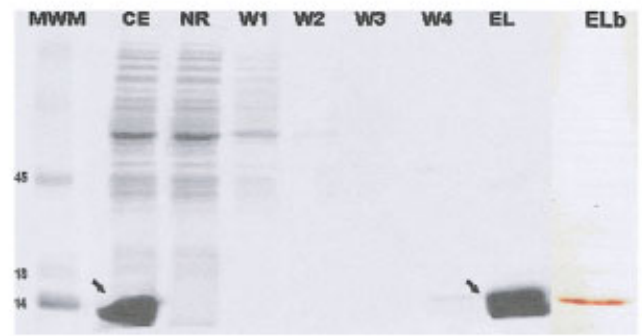

B

Fig. 1. (A) Ni-NTA chromatographic steps of heterologous CCPI purification. Inhibitory activity of fractions was determined against commercial papain. (B) SDS-PAGE analysis of the chromatographic fractions; gel stained by Coomassie-Blue. All samples loaded contained $56 \mu \mathrm{g}$ of protein. Black arrows point at cowpea cystatin. (CE, crude extract of induced E. coli cells; NR, nonretained fraction; W1, W2, W3, and W4, sequential washed fractions; EL, eluted protein fraction; ELb, Eluted fraction probed with an anti-CCPI serum.)

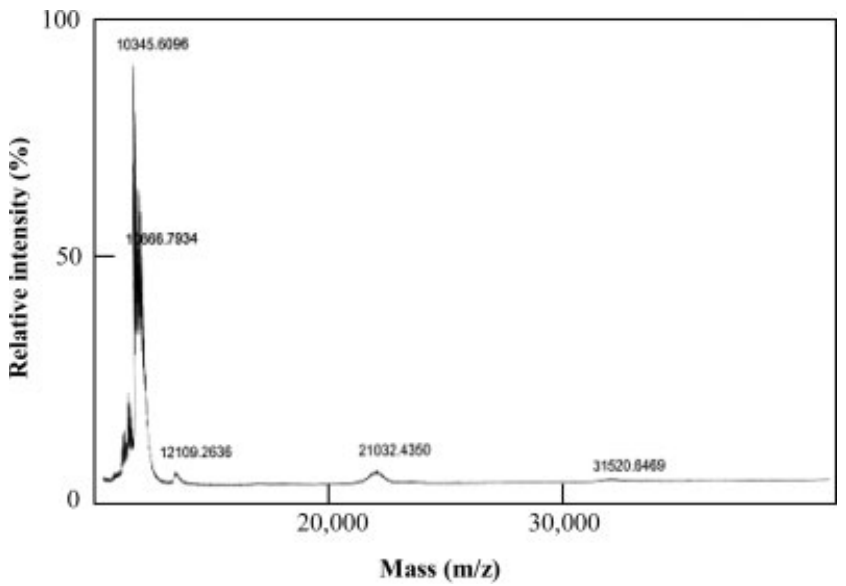

Fig. 2. MALDI-TOF mass spectrum of purified CCPI (eluted fraction).

bean weevils but was inactive against the proteinases from both Anthonomus grandis larvae (AgL) and adults (AgA). These results are in agreement with data regarding the composition of digestive enzymes in these tested species. In $A$. grandis midgut, cysteine proteinases constitute a minority of digestive proteinases, ${ }^{64}$ in contrast to their abundance in bean weevils. ${ }^{34,65}$

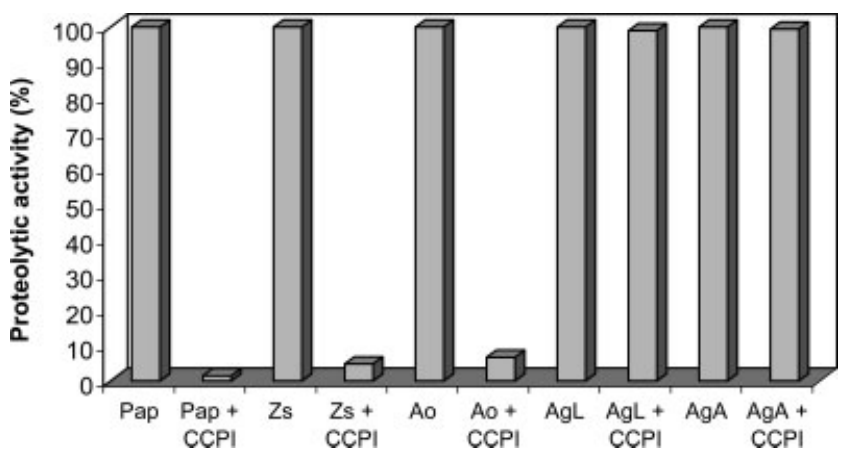

Fig. 3. Inhibitory activities of CCPI towards papain (Pap) and bruchid proteinases from Z. subfasciatus (Zs), A. obtectus (Ao), and Anthonomus gradis $(\mathrm{Ag})$. Data obtained from three replicate assays.

The results also reinforce previous data on in vitro inhibition of proteinases from coleopterans by cystatins from soybean, ${ }^{66}$ corn,${ }^{9}$ rice,${ }^{67}$ and chestnut, ${ }^{68}$ but comparisons are sometimes complicated by methodological differences. A direct comparison can be made with the results of Hines et al., ${ }^{6}$ who assayed soybean cystatin against papain and gut extracts from $A$. obtectus and $C$. maculatus. This reveals a much higher activity of CCPI than of soybean cystatin, against both papain and $A$. obtectus extract. An amount of $100 \mathrm{ng}$ of CCPI inhibits papain and A. obtectus midgut extract by 98 and $93 \%$, respectively. The same amount of soybean cystatin inhibits papain by around $30 \%$, while $200 \mathrm{ng}$ are necessary for $22 \%$ inhibition of the A. obtectus extract. However, Koiwa et al. ${ }^{14}$ demonstrated a different inhibitory potential for two soybean cystatins ( $\mathrm{scN}$ and $\mathrm{scL}$ ) when evaluating $C$. maculatus growth (assessed by the within-seed developmental time parameter) and mortality. The former $\mathrm{scN}$, at a $0.5 \% \mathrm{w} / \mathrm{w}$ concentration, retarded growth (50\% of retardation) and increased in $50 \%$ mortality rate of cowpea weevil, while the latter scL affected neither growth nor mortality.

Although CCPI strongly inhibits midgut cysteine proteinases of the cowpea weevil Callosobruchus maculatus, ${ }^{34}$ these inhibitors are expressed at levels too low to have an impact on seed predation by this bruchid. ${ }^{69}$ Also, the levels of cysteine proteinase inhibitors and the populations of mRNAs $^{38}$ are similar in seeds of susceptible and resistant lines of cowpea, indicating that cystatins do not contribute to cowpea resistance to $C$. maculatus.

\section{Bean Weevils Feeding Assays}

Prompted by the in vitro inhibitory potential of CCPI over the bruchid proteolytic enzymes, a series of in vivo experiments were carried out. The effects of CCPI on the development of larvae, when incorporated into an artificial diet, were investigated. Strikingly, even at the lowest level of $0.025 \%$, CCPI lead to significant increases of around $79 \%$ in the case of $A$. obtectus and $67 \%$ for $Z$. subfasciatus in adult insect mortality [Fig. 4(b)]. These rates are compared to a $10 \%$ of mortality of control experiments. At the highest levels of cystatin incorporation, A. obtectus mortality approaches $100 \%$ while $Z$. subfasciatus mortality nears $90 \%$ [Fig. 4(b)]. Almost as dramatic are the 

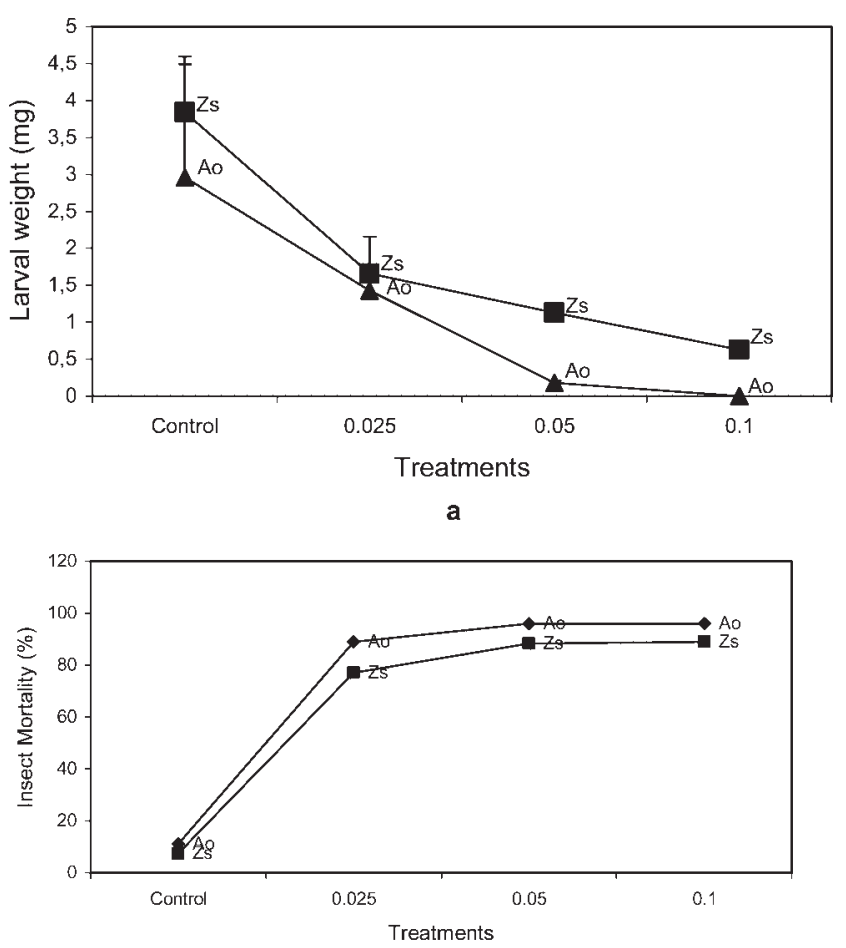

b

Fig. 4. Effects of CCPI on (a) weight ( $\pm \mathrm{SD}$ ) and (b) on mortality of $Z$. subfasciatus and $A$. obtectus larvae relative to the control. Each value represents the weight of 27 larvae. Each mean represent three replicates.

reductions in larval weight observed in the presence of CCPI at all levels [Fig. 4(a)]. The lowest amount (0.025\%) is able to significantly reduce larval weights $(>50 \%)$ for both species, while further weight reductions are seen at higher cystatin concentrations. Interestingly, larvae that reached the adult stage (the surviving adults) from these studies show no weight reduction when compared to controls (data not shown).

Until this time, only $\alpha$-amylase inhibitors from wheat and rye showed potential as defense factor against the bean weevil A. obtectus. ${ }^{70,71}$ On the other hand, the high levels of digestive cysteine proteinases present in bean weevil's midguts turn these enzymes good targets for controlling these pests. We report in this work in vivo effects of cowpea cystatin on the survival and development of both A. obtectus and Z. subfasciatus. Levels as low as $0.025 \%$ of this protein, when incorporated in artificial diet, lead to increases of around 79\% in the case of A. obtectus and $67 \%$ for $Z$. subfasciatus in adult insect mortality [Fig. 4(b)]. Almost as dramatic were the reductions in larval weight observed in the presence of CCPI at all tested levels [Fig. 4(a)]. In line with this potency of cowpea cystatin in vivo, comparisons of these data with previous studies reveal this inhibitor as being highly effective against the tested bruchids, even at low levels. For example, equistatin, a thyroglobulin type-1 domain-like inhibitor has been used in feeding assays against the Colorado potato beetle Leptinotarsa decemlineata. ${ }^{72}$ At a level of $0.3 \%$ in a potato leaf diet, a $50 \%$ mortality rate was seen. ${ }^{72}$ The present work shows that $0.05 \%$ of CCPI caused bean weevil mortality of around 95\%. In another study, $11.27 \mu \mathrm{M}$ of soybean cystatin $\mathrm{scNM}^{8-103}$ caused $50 \%$ of larval weight reduction for western corn rootworm (Diabrotica virgifera $).{ }^{73}$ Soybean cystatin $\mathrm{scNM}^{8-103}$ when incorporated in an artificial diet at a $0.5 \%$ level caused $50 \%$ of insect mortality. ${ }^{14}$ At a level of $0.1 \%$, CCPI gave mortality rates of 89 and $96 \%$ for $Z$. subfasciatus and A. obtectus, respectively.

\section{Modeling of the Papain-CCPI Complex}

The results of the sequences comparisons and threading analyses suggest that chicken egg cystatin (PDB code 1cew) would provide a good template for constructing a model for CCPI. Further down the list of favorable structures appear stefins, both uncomplexed (PDB code $1 \mathrm{dvd}$ ) and in complex with papain (PDB code 1stf; 44), and monellin (PDB code 1mol; 45). For example, the FFAS method give chicken cystatin a Z-score of 61 , the stefins scores of 22 and monellin a score of 9 . The chosen modeling strategy therefore made use of structural information from both stefins and chicken cystatin, for regions of structural similarity, and chicken cystatin where the templates differed. The alignment used is shown in Figure 5. The papain-stefin complex structure was used to model the termini of CCPI (where the stefins are longer than chicken cystatin) and to provide the papain part of the final model.

Analysis of the papain-CCPI modeled complex (Fig. 6) shows favorable packing and solvent exposure characteristics with the best-scoring model giving an overall PROSA II figure of -10.35 , comparing well with the corresponding -13.15 scored by the papain-stefin complex. Similarly, the overall stereochemical qualities of the papain-CCPI modeled complex were good, as indicated by an overall PROCHECK G-factor of -0.23 , slightly better than the -0.28 scored by 1 stf. PROSA II profile analysis, highlighted several unusually exposed hydrophobic residues among CCPI residues 73-88, containing the last two $\beta$-strands of the structure. However, the alignment of CCPI with 1cew is very clear for this region, and a similar PROSA II peak is seen in the profile of 1cew. In fact, two of the exposed hydrophobic residues are important in the interaction between enzyme and inhibitor, as seen in Figure 6.

\section{Analysis of the Papain-CCPI Interface of the Final Model}

Although analyses of protein-protein interfaces highlight different aspects of the interaction, ${ }^{58,74}$ simple surface complementarity is known to be a key factor. ${ }^{75}$ It was therefore important that the $\mathrm{SC}^{55}$ number for the final model of 0.67 compares favorably with the range 0.70 0.76 observed for experimentally determined structures. Comparison of interface interaction energies reveals the final model to be somewhat less favorable than 1stf with a value of $-26.5 \mathrm{kcal} / \mathrm{mol}$ compared to $-42.5 \mathrm{kcal} / \mathrm{mol}$, although the model interface has more hydrogen bonds (eight compared to six) and more hydrophobic contacts (56 vs. 52). In the papain-CCPI model hydrophobic interactions predominate over hydrogen bonds ( 56 compared to 8 ) 


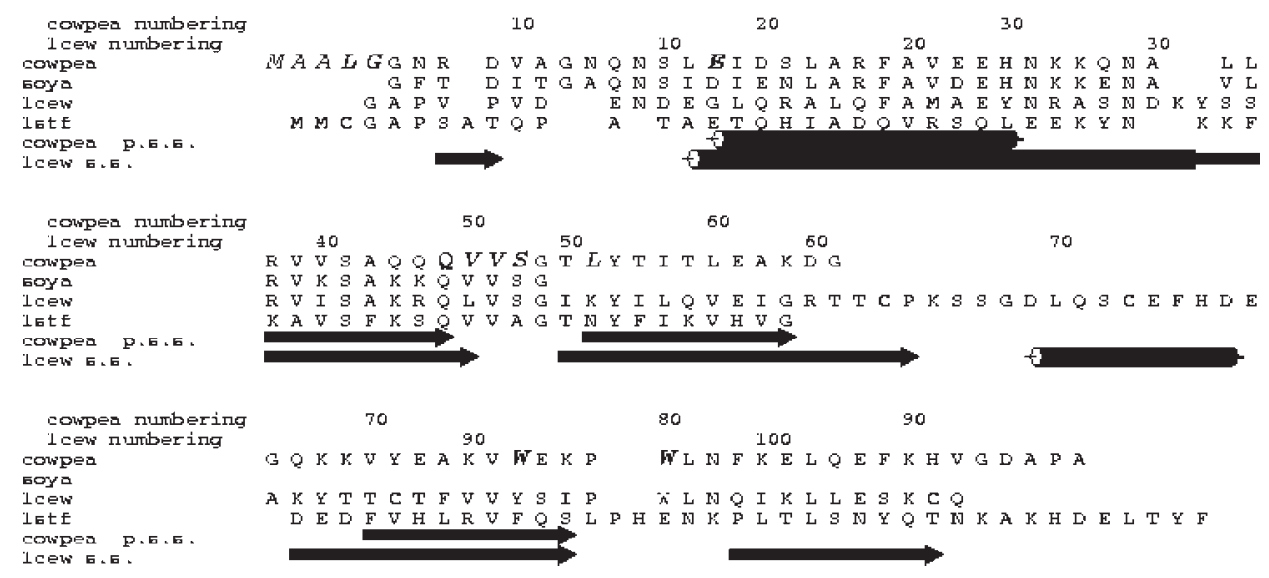

Fig. 5. Sequence alignment of CCPI with the partial sequence of the soya homolog 77 and sequences of the two structures used for modeling-PDB codes 1 cew (chicken egg white cystatin ${ }^{43}$ ) and 1 stf (human stefin $\mathrm{B}^{44}$ ). The alignment of $1 \mathrm{cew}$ and $1 \mathrm{stf}$ is the structural alignment taken from the FSSP database. ${ }^{51}$ For CCPI and 1 cew, numbering is shown above the alignment and secondary structure, predicted and actual respectively, below the alignment. CCPI residues forming hydrogen bonds with papain in the final complex model are emboldened and those making hydrophobic interactions italicized. The figure was made with Alscript. ${ }^{84}$

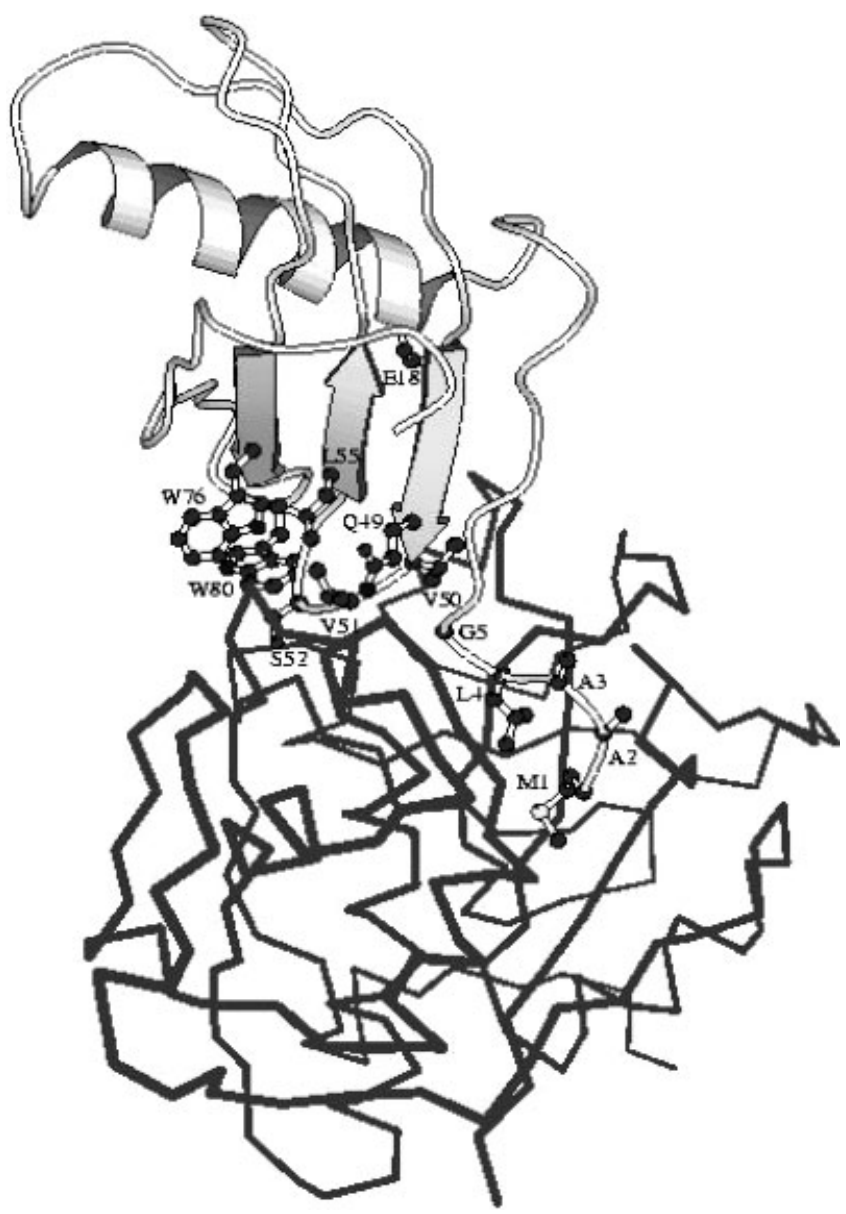

Fig. 6. Molscript ${ }^{85}$ diagram of the final model of papain in complex with CCPI. The papain portion (below) is shown as a gray $\mathrm{C} \alpha$ trace and the cystatin (above) as a ribbon diagram. Side chains of cystatin residues interacting with the enzyme are drawn in a ball-and-stick representation and labeled. The orientation was chosen to clearly display the role of the inhibitor N-terminus leading to partial concealment of residue Glu 18. at the interface and the electrostatic interaction energy of the model is unfavorable. Interestingly, both these characteristics are shared by the papain-stefin B structure, ${ }^{44}$ suggesting that they may be typical of protease-cystatin interactions in general.

Figure 6 shows that CCPI interactions with the enzyme are confined mainly to three regions, the N-terminus, the well-characterized consensus loop (residues 49-53, sequence QVVSG in CCPI), and a second hairpin loop along with its preceding beta strand. Outside of these regions the only predicted enzyme-inhibitor interaction is between Glu 18 and Lys 139 of papain, the only direct ionic interaction between the two molecules.

Detailed examination of the contacts shows a key role for the N-terminal region of CCPI; 35 of the 56 hydrophobic interface interactions involve residues Met 1 to Gly 5. Particularly important are Met 1 and Leu 216, which contribute for 20 and 11 interactions, respectively. The analysis also shows that these two side chains bind into a largely hydrophobic surface pocket of papain lined by Phe 207, Pro 68, Val 133, Ala 160, Trp 26, and Cys 25. Also noteworthy are the hydrophobic contributions to binding of two solvent-exposed hydrophobic residues of the inhibitor, Trp 80 of the second hairpin loop ${ }^{44}$ and Trp 76 on the preceding $\beta$-strand (Fig. 6). Trp 80 lies against a hydrophobic patch on the surface of the enzyme caused by the positioning of residues Trp 177 and Trp 181.

Confinement of interactions between the CCPI and papain to three major regions, the $\mathrm{N}$-terminus, the consensus QXVXG loop, and a second hairpin loop, is in accord with the papain-stefin complex, ${ }^{44}$ as well as for five other protease-inhibitor complexes formed between AtCYS1 (Arabidopsis thaliana cystatin), oryzacystatin-I, chicken egg white cystatin, and human stefins A and B to papain. ${ }^{76}$ Although only a partial, N-terminal sequence of the soybean cystatin is available ${ }^{77}$ (Fig. 5), it immediately suggests a possible explanation for the lesser inhibitory power of this homologue ${ }^{6}$ in comparison to CCPI (Fig. 3). The 
soybean cystatin, while exhibiting $67 \%$ of sequence identity with CCPI, lacks five $\mathrm{N}$-terminal residues. The modeling shows these five to be responsible for a large proportion of the hydrophobic interactions suggested as primarily responsible for stabilizing the enzyme-inhibitor interface. Although additional favorable interactions may be made by the unknown portion of the soybean cystatin, its shorter $\mathrm{N}$-terminus may well contribute to its relatively weak inhibition of cysteine proteases. ${ }^{6}$

\section{CONCLUSION}

Transgenic plant technology may provide a major contribution to the production of crop varieties that are tolerant to insect pests. However, aspects of specificity and potency of target genes are quintessential points to be carefully thought about.

In this article, the main finding was that cowpea cystatin seems to have unusually high inhibitory activity in vitro, and is correspondingly highly effective in vivo against two economically important crop pests. Potency is a key consideration in the planning of transgenic plants because high level expression of heterologous genes is not always possible. The effectiveness of other proteinase inhibitors at level from tenths to several percent of total soluble protein ${ }^{78,79}$ highlights the potential of CCPI with its dramatic effects on insect mortality and larval development at much lower levels. We envisage this inhibitor as a strong candidate, either alone or in combination with other toxic proteins, for the production of transgenic bean plants with increased resistance to weevil pests. Another noticeable aspect is that this plant protein presents no toxicity against mammal's proteases. ${ }^{80}$ In the future the increased understanding of the cystatin-cysteine protease interaction afforded by the modeling presented here may lead to rationally mutated cystatins with improved affinity. In this field cystatins, modified or not, represent good candidate genes for the production of transgenic plants resistant to bruchid insect-pest. ${ }^{81}$ The realization that closely related cystatins have such different potencies should also encourage further biochemical screening, as carried out by Melo et al., ${ }^{82}$ where two selected variant cystatins have increased their specificity towards $A$. obtectus cysteine proteinases when compared to the original sequence, by phage display technology. Flores et al. ${ }^{83}$ have yet suggested that specific cystatin isoforms from a single plant species could have metabolic or protective functions, recognizing either different endogenous enzymes or enzymes from different pathogens or pests. In this manner, further studies on effects of introduced cystatin genes on processes such as seed germination of transformed plants, considering the proposed role of cysteine proteinase inhibitors in regulating the activity of endogenous enzymes, are also an expectation of this science field.

\section{ACKNOWLEDGMENTS}

We thank to Dr. Peter Urwin for the pQE30/CCPI clone and Charles Dayler for technical assistance. Capes, CNPq, FAPERJ, FENORTE, and FAPDF supported this work.

\section{REFERENCES}

1. Ryan CA. Protease inhibitors in plants-genes for improving defenses against insects and pathogens. Annu Rev Phytopathol 1990;28:425-449.

2. Urwin P, Lilley CJ, McPherson MJ, Atkinson HJ. Resistance to both cyst and root-knot nematodes conferred by transgenic Arabidopsis expressing a modified plant cystatin. Plant J 1997;12:455461.

3. Jongsma MA, Bolter C. The adaptation of insects to plant protease inhibitors. J Insect Physiol 1997;43:885-895.

4. Botella MA, Xu Y, Prabha TN, Zhao Y, Narasimhan ML, Wilson KA, Nielsen SS, Bressan RA, Hasegawa PM. Differential expression of soybean cysteine proteinase inhibitor genes during development and in response to wounding and methyl jasmonate. Plant Physiol 1996;112:1201-1210.

5. Jacinto T, Fernandes KVS, Machado OLT, Siqueira-Júnior CL. Leaves of transgenic tomato plants overexpressing prosystemin accumulate high levels of cystatin. Plant Sci 1998;138:35-42.

6. Hines ME, Osuala CI, Nielsen SS. Isolation and partial characterization of a soybean cystatin cysteine proteinase inhibitor of Coleopteran digestive proteolytic activity. J Agric Food Chem 1991;39:1515-1520.

7. Chen Ms, Johnson B, Wen L, Muthukrishnan S, Kramer KJ, Morgan TD, Reeck GR. Rice cystatin-bacterial expression, purification, cysteine proteinase inhibitory activity, and insect growth suppressing activity of a truncated form of the protein. Protein Expr Purif 1992;3:41-49.

8. Michaud D, Nguyenquoc B, Yelle S. Selective-inhibition of Colorado potato beetle cathepsin-h by oryzacystatin-I and oryzacystatin-II. FEBS Lett 1994;339:313-313.

9. Irie K, Hosoyama H, Tabeuchi T, Iwabuchi K, Watanabe H, Abe M, Abe K, Arai S. Transgenic rice established to express corn cystatin exhibits strong inhibitory activity against insect gut proteinases. Plant Mol Biol 1996;30:149-157.

10. Kuroda M, Ishimoto M, Suzuki K, Kondo H, Abe K, Kitamura K, Arai S. Oryzacystatins exhibit growth-inhibitory and lethal effects on different species of bean insect pests Callosobruchus chinensis (Coleoptera) and Riptortus clavatus (Hemiptera). Biosci Biotechnol Biochem 1996;60:209-212.

11. Lim CO, Lee SI, Chung WS, Park SH, Hwang I, Cho MJ. Characterization of a cDNA encoding cysteine proteinase inhibitor from Chinese cabbage (Brassica campestris L ssp pekinensis) flower buds. Plant Mol Biol 1996;30:373-379.

12. Misaka T, Kuroda M, Iwabuchi K, Abe K, Arai S. Soyacystatin, a novel cysteine proteinase inhibitor in soybean, is distinct in protein structure and gene organization from other cystatins of animal and plant origin. Eur J Biochem 1996;240:609-614

13. Walker AJ, Urwin PE, Atkinson HJ, Brain P, Glen DM, Shewry PR. Transgenic Arabidopsis leaf tissue expressing a modified oryzacystatin shows resistance to the field slug Deroceras reticulatum (Müller). Transg Res 1999;8:95-103.

14. Koiwa H, Shade RE, Zhu-Salzman K, Subramanian L, Murdock LL, Nielsen SS, Bressan RA, Hasegawa PM. Phage display selection can differentiate insecticidal activities of soybean cystatins. Plant J 1998;14:371-379.

15. Pernas M, Lopez-Solanilla E, Sanchez-Monge R, Salcedo G, Rodriguez-Palenzuela P. Antifungal activity of a plant cystatin. Mol Plant-Microbe Interact 1999;12:624-627.

16. Masoud SA, Johnson LB, White FF, Reeck GR. Expression of a cysteine proteinase inhibitor (oryzacystatin-I) in transgenic tobacco plants. Plant Mol Biol 1993; 21:655-663.

17. Hosoyama H, Irie K, Abe K, Arai S. Oryzacystatin exogenously introduced into protoplasts and regeneration of transgenic rice. Biosci Biotechnol Biochem 1994;58:1500-1505.

18. Benchekroun A, Michaud D, Nguyenquoc B, Overney S, Desjardins Y, Yelle S. Synthesis of active oryzacystatin-I in transgenic potato plants. Plant Cell Rep 1995;14:585-588.

19. Urwin P, Atkinson HJ, Waller DA, McPherson MJ. Engineered oryzocystatin-I expressed in transgenic hairy roots confers resistance to Globodera pallida. The Plant J 1995;8:121-131.

20. Leplé JC, Bonade-Botinno M, Augustin S, Pilate G, Ce Tan VD, Delplanque A, Cornu D, Jouanin L. Toxicity of Chrysomela tremulae (Coleoptera: Crysomelidae) of transgenic poplars expressing a cysteine proteinase inhibitor. Mol Breed 1995;1:319-328.

21. Atkinson HJ, Urwin PE, Clarke MC, McPherson MJ. Image analysis of the growth of Globodera pallida and Meloidogyne 
incognita on transgenic tomato roots expressing cystatins. J Nematol 1996;28:209-215.

22. Atkinson HJ, Grimwood S, Johnston K, Green J. Prototype demonstration of transgenic resistance to the nematode Radopholus similis conferred on banana by a cystatin. Transg Res 2004;13: 135-142.

23. Lawrence PK, Koundal KR. Plant protease inhibitors in control of phytophagous insects. J Nematol 2002;28:209-215.

24. Outchkourov NS, de Kogel WJ, Wiegers GL, Abrahamson M, Jongsma MA. Engineered multidomain cysteine protease inhibitors yield resistance against western flower thrips (Franklinielia occidentalis) in greenhouse trials. Plant Biotechnol J 2004;2:449_ 458.

25. Outchkourov NS, de Kogel WJ, Schuurman-de Bruin A, Abrahamson M, Jongsma MA. Specific cysteine protease inhibitors act as deterrents of western flower thrips, Frankliniella occidentalis (Pergande), in transgenic potato. Plant Biotechnol J 2004;5:439448.

26. Arai S, Abe K. Cystatin-based control of insects with special reference to the efficacy of oryzacystatin. In: Michaud D, editor. Recombinant proteinase inhibitors in plants.Georgetown TX: Landes; 2000. p 27-42.

27. Atkinson HJ, Green J, Cowgill S, Levesley A. The case for genetically modified crops with a poverty. Trends Biotechnol 2001;19:91-96.

28. Lilley CJ, Devlin F, Urwin PE, Atkinson HJ. Parasitic nematodes, proteinases and transgenic plants. Parasitol Today 1999;15:414417.

29. Lilley CJ, Urwin PE, Johnston KA, Atkinson HJ. Preferential expression of a plant cystatin at nematode feeding sites confers resistance to Meloidogyne incognita and Globodera pallida. Plant Biotechnol J 2004;2:3-12.

30. Joshi BN, Sainani MN, Bastawade KB, Gupta VS, Ranjekar PK. Cysteine protease inhibitor from pearl millet: a new class of antifungal protein. Biochem Biophys Res Commun 1998;246:382387.

31. Pernas M, Sanchez-Mong R, Salcedo G. Biotic and abiotic stress can induce cystatin expression in chestnut. FEBS Lett 2000;467: $206-210$.

32. Siqueira-Júnior CL, Fernandes KVS, Machado OLT, da Cunha M, Gomes VM, Moura D, Jacinto T. $87 \mathrm{kDa}$ tomato cystatin exhibits properties of a defense protein and forms protein crystals in prosystemin overexpressing transgenic plants. Plant Physiol Biochem 2002;40:247-254.

33. Soares-Costa A, Beltramini LM, Thiemann OH, Henrique-Silva F. A sugarcane cystatin: recombinant expression, purification, and antifungal activity. Biochem Biophys Res Commun 2002;296:11941199.

34. Campos FAP, Xavier-Filho J, Silva CP, Ary MB. Resolution and partial characterization of proteinases and $\alpha$-amylases from midguts of larvae of the bruchid beetle Callosobruchus maculatus (F.). Comp Biochem Physiol 1989;92:51-57.

35. Jansen DH. The defenses of legumes against herbivores. In: Polhill RM, Raven PH, editors. Advances in legumes systematics. London: Academic Press; 1981. p 951-977.

36. Broadway RM. Dietary proteinase inhibitors alter complement of midgut proteases. Arch Insect Biochem Physiol 1996;32:39-53.

37. Chrispeels MJ. Transfer of bruchid resistance from the common bean to other starchy grain legumes by genetic engineering with the a-amylase inhibitor gene. In: Carozzi N, Koziel M, editors. Transgenic plants for control of insect pests. London: Taylor \& Francis; 1996. p 1-10.

38. Fernandes KVS, Sabelli PA, Barratt DHP, Richardson M, XavierFilho J, Shewry PR. The resistance of cowpea seeds to bruchid beetles is not related to levels of cysteine proteinase-inhibitors. Plant Mol Biol 1993;23:215-219.

39. Laemmli UK. Cleavage of structural proteins during the assembly of the head of bacteriophage T4. Nature 1970;227:680-685.

40. Towbin H, Staehelin T, Gordon J. Electrophoretic transfer of proteins from polyacrylamide gels to nitrocellulose sheets: procedure and some applications. Proc Natl Acad Sci USA 1979;76:43504354 .

41. Monnerat R, Dias SC, Oliveira-Neto B, Nobre SD, Grossi de Sá MF. Criação de bicudo do algodoeiro Anthonomus grandis em dieta artificial e estabelecimento para bioensaios com Bacillus thuringiensis. IV Congresso Brasileiro de Algodão, Ribeirão Preto, SP, 1999; p 214-216.
42. Barrett AJ, Kirschke H. Cathepsin B, cathepsin H, and cathepsin L. Methods Enzymol 1981;80:535-561.

43. Bode W, Engh R, Musil D, Thiele U, Huber R, Karshikov A, Brzin J, Kos J, Turk V. The 2.0 A X-ray crystal structure of chicken egg white cystatin and its possible mode of interaction with cysteine proteinases. EMBO J 1988;7:2593-2599.

44. Stubbs MT, Laber B, Bode W, Huber R, Jerala R, Lenarcic B, Turk $\mathrm{V}$. The refined 2.4 A X-ray crystal structure of recombinant human stefin B in complex with the cysteine proteinase papain: a novel type of proteinase inhibitor interaction. EMBO J 1990;9:19391947.

45. Somoza JR, Jiang F, Tong L, Kang CH, Cho JM, Kim SH. Two crystal structures of a potently sweet protein. Natural monellin at $2.75 \AA$ resolution and single-chain monellin at $1.7 \AA$ resolution. J Mol Biol 1993;234:390-404.

46. Karplus K, Barrett C, Hughey R. Hidden Markov models for detecting remote protein homologies. Bioinformatics 1998;14:846856.

47. Rychlewski L, Jaroszewski L, Li W, Godzik A. Comparison of sequence profiles. Strategies for structural predictions using sequence information. Protein Sci 2000;9:232-241

48. Jones DT. GenTHREADER: an efficient and reliable protein fold recognition method for genomic sequences. J Mol Biol 1999;287: 797-815.

49. Kelley LA, MacCallum RM, Sternberg MJE. Enhanced genome annotation using structural profiles in the program 3D-PSSM. J Mol Biol 2000;299:501-522.

50. Fischer D. Hybrid Fold recognition: combining sequence derived properties with evolutionary information. Pacific Symp Biocomputing, Hawaii; 2000. p 119-130.

51. Holm L, Sander C. Mapping the protein universe. Science 1996;273: 595-603.

52. Rigden DJ, Carneiro M. A structural model for the rolA protein and its interaction with DNA. Proteins 1999;37:697-708.

53. Rigden DJ, Mello LV, Bertioli DJ. Structural modelling of a plant disease resistance gene product domain. Proteins 2000;41:133143.

54. Sippl MJ. Recognition of errors in three-dimensional structures of proteins. Proteins 1993;17:355-362.

55. Laskowski R, MacArthur M, Moss D, Thornton J. PROCHECK: a program to check stereochemical quality of protein structures. J Appl Crystallogr 1993;26:283-290.

56. Jackson JC, Vinluan CC, Dragland CJ, Sundararajan V, Yan B, Gounarides JS, Nirmala NR, Topiol S, Ramage P, Blume JE, Aicher TD, Bell PA, Mann WR. Heterologously expressed inner lipoyl domain of dihydrolipoyl acetyltransferase inhibits ATPdependent inactivation of pyruvate dehydrogenase complexidentification of important amino acid residues. Biochem J 1998; 334:703-711.

57. Brünger AT. Available on the WWW at http://xplor.csb.yale.edu/ xplor-info/xploronline.html; 1999.

58. Jones S, Thornton JM. Principles of protein-protein interactions derived from structural studies. Proc Natl Acad Sci USA 1996;93: 13-20.

59. Lawrence MC, Colman PM. Shape complementarity at protein/ protein interfaces. J Mol Biol 1993;234:946-950.

60. McDonald IK, Thornton JM. Satisfying hydrogen-bonding potential in proteins. J Mol Biol 1994;238:777-793.

61. Gruden K, Strukelj B, Ravnikar M, Poljsak-Prijatel M, Mavric I, Brzin J, Pungencar J, Kregar I. Potato cysteine proteinase inhibitor gene family: molecular cloning, characterization and immunocytochemical localization studies. Plant Mol Biol 1997;34:317323.

62. Doi-Kawano K, Kouzuma Y, Yamasaki N, Kimura M. Molecular cloning, functional expression and mutagenesis of cDNA encoding a cysteine proteinase inhibitor from sunflower seeds. J Biochem 1998;124:911-916.

63. Arai S, Matsumoto I, Emori Y, Abe K. Plant seed cystatins and their target enzymes of endogenous and exogenous origin. J Agric Food Chem 2002;50:6612-6617.

64. Purcell JP, Greenplate JT, Sammons RD. Examination of midgut luminal proteinase activities in six economically important insects. Insect Biochem Mol Biol 1992;22:41-47.

65. Silva CP, Xavier-Filho J. Comparison between the levels of aspartic and cysteine proteinases of the larval midguts of Callosobruchus maculatus (F.) and Zabrotes subfasciatus (BOH.) (Coleoptera: Bruchidae). Comp Biochem Physiol 1991;99:529-533. 
66. Zhao Y, Botella MA, Subramanian L, Niu X, Nielsen SS, Bressan RA, Hasegawa PM. Two wound-inducible soybean cysteine proteinase inhibitors have greater insect digestive proteinase inhibitory activities than a constitutive homolog. Plant Physiol 1996;111: $1299-1306$.

67. Liang C, Brookhart G, Feng GH, Reeck GR, Kramer KJ. Inhibition of digestive proteinases of stored grain coleoptera by oryzacystatin, a cysteine proteinase inhibitor from rice seed. FEBS Lett 1991;278:139-142.

68. Pernas M, Sanchez-Monge R, Gómez L, Salcedo G. A chestnut seed cystatin differentially effective against cysteine proteinases from closely related pests. Plant Mol Biol 1998;38:1235-1242.

69. Xavier-Filho J, Campos FAP, Ary MB, Silva CP, Carvalho MMM, Macedo MLR, Lemos FJA, Grant G. Poor correlation between the levels of proteinase inhibitors found in seeds of different cultivars of cowpea (Vigna unguiculata) and the resistance/susceptibility to predation by Callosobruchus maculates. J Agric Food Chem 1989;37:1139-1143.

70. Franco OL, Rigden DJ, Melo FR, Bloch C Jr, Silva CP, Grossi de Sá, MF. Activity of wheat $\alpha$-amylase inhibitors towards bruchid $\alpha$-amylases and structural explanation of observed specificities. Eur J Biochem 2000;267:2166-2173.

71. Iulek J, Franco OL, Silva M, Slivinski CT, Bloch C Jr, Rigden DJ, Grossi de Sá MF. Purification, biochemical characterisation and partial primary structure of a new $\alpha$-amylase inhibitor from Secale cereale (Rye). Int J Biochem Cell Biol 2000;32:1195-1204.

72. Gruden K, Strukelj B, Popovic T, Lenarcic B, Bevec T, Brzin J, Kregar I, Herzog-Velikonja J, Stiekema WJ, Bosch D, Jongsma MA. The cysteine protease activity of Colorado potato beetle (Leptinotarsa decemlineata Say) guts, which is insensitive to potato protease inhibitors, is inhibited by thyroglobulin type-1 domain inhibitors. Insect Biochem Mol Biol 1998;28:549-560.

73. Koiwa H, Shade RE, Zhu-Salzman K, D’Urzo MP, Murdock LL, Bressan RA, Hasegawa PM. A plant defensive cystatin (soyacystatin) targets cathepsin L-like digestive cysteine proteinases (DvCALs) in the larval midgut of western corn rootworm (Diabrotica virgifera virgifera). FEBS Lett 2000;471:67-70.

74. Lo Conte L, Chothia C, Janin J. The atomic structure of proteinprotein recognition sites. J Mol Biol 1999;285:2177-2198.
75. Norel R, Petrey D, Wolfson HJ, Nussinov R. Examination of shape complementarity in docking of unbound proteins. Proteins 1999;15: 307-317.

76. Belenghi B, Acconcia F, Trovato M, Perazzolli M, Bocedi A, Polticelli F, Ascenzi P, Delledonne M. AtCYS1, a cystatin from Arabidopsis thaliana, suppresses hypersensitive cell death. Eur J Biochem 2003;270:2593-2604.

77. Brzin J, Ritonja A, Popovic T, Turk V. Low molecular mass protein inhibitor of cysteine proteinases from soybean. Biol Chem HoppeSeyler 1990;371:167-170.

78. Schroeder HE, Gollash S, Moore A, Tabe LM, Craig S, Hardie D, Chrispeels MJ, Spencer D, Higgins TJV. Bean $\alpha$-amylase inhibitor confers resistance to the pea weevil, Bruchus pisorum, in genetically engineered peas (Pisum sativum L.). Plant Physiol 1995;107: 1233-1239.

79. Jouanin L, Bonadé-Bottino M, Girard C, Morrot G, Giband M. Transgenic plants for insect resistance. Plant Sci 1998;131:1-11.

80. Carlini CR, Grossi-de-Sá MF. Plant toxic proteins with insecticidal properties. A review on their potentialities as bioinsecticides. Toxicon 2002;40:1515-1539.

81. Haq SK, Atif SM, Khan RH. Protein proteinase inhibitor genes in combat against insects, pests, and pathogens: natural and engineered phytoprotection. Arch Biochem Biophys 2004;431:145159.

82. Melo FR, Mello MO, Franco OL, Rigden DJ, Mello LV, Genu AM, Silva-Filho MC, Gleddie S, Grossi-de-Sa MF. Use of phage display to select novel cystatins specific for Acanthoscelides obtectus cysteine proteinases. Biochim Biophys Acta 2003;1651:146-152.

83. Flores VMQ, Louro RP, Xavier-Filho J, Barratt DHP, Shewry PR, Fernandes KVS. Temporal and tissue localization of a cowpea (Vigna unguiculata) cystatin. Physiol Plantarum 2001;112:195199.

84. Barton GJ. ALSCRIPT, a tool to format multiple sequence alignments. Protein Eng 1993;6:37-40.

85. Kraulis J. MOLSCRIPT: a program to produce both detailed and schematic plots of protein structures. J Appl Crystallogr 1991;24: 946-950. 